\title{
ANALISIS KONDISI TINGKAT KEPERCAYAAN MASYARAKAT AKIBAT MERGER BANK SYARIAH INDONESIA
}

\author{
David Novaldi \\ Universitas Islam Negeri Raden Intan Lampung \\ Muhammad Iqbal Fasa* \\ Universitas Islam Negeri Raden Intan Lampung \\ Suharto \\ Universitas Islam Negeri Raden Intan Lampung \\ Lita Monalysa \\ STEBI Lampung
}

\begin{abstract}
The Merger of Sharia BUMN Bank which was carried out in early 2021 resulted in changes both internally and externally. One of parties that will feel the impact of the merger of Bank Syariah Indonesia is the customer. The level of customer confidence in a bank is considered very important for the sustainability of a bank. This research is expected to be able to analyze the level of public trust in Bank Syariah Indonesia is the result of the merger of 3 Sharia BUMN Bank. This research uses quantitative methods and data collection is done by library method from journal, article, or literature related to the required data, and documentation method of sharia commercial bank implementation report in question as well as data from OJK website. In this study, it is explained that the merger of Islamic banks has an influence on the level of trust of the community. The public expects that Islamic banking is able to compete and improve people's lives.
\end{abstract}

Keywords: Merger, Public Trust, Sharia Banking

Paper type: Research paper

*Corresponding author: miqbalfasa@ radenintan.ac.id

Received: April 24, 2021; Accepted: November 13, 2021; Available online: December, 06, 2021

Cite this document:

Novaldi, D., Fasa, M. I., Suharto, \& Monalysa, L. (2021). Analisis Kondisi Tingkat Kepercayaan Masyarakat Akibat Merger Bank Syariah Indonesia. Jurnal Masharif Al-Syariah: Jurnal Ekonomi dan Perbankan Syariah, 6(3), 754-776. doi:http://dx.doi.org/10.30651/jms.v6i3.8050

Copyright (C) 2021, Jurnal Masharif Al-Syariah: Jurnal Ekonomi dan Perbankan Syariah http://journal.um-surabaya.ac.id/index.php/Mas/index

This article is licensed under a Creative Commons Attribution-NonCommercial 4.0 International License. 


\begin{abstract}
Abstrak
Merger Bank BUMN Syari'ah yang dilakukan awal 2021 mengakibatkan perubahan baik internal maupun eksternal. salah satu pihak yang merasakan dampak dari merger Bank Syari'ah Indonesia adalah nasabah. Tingkat kepercayaan nasabah pada suatu bank dinilai sangat penting bagi keberlangsungan suatu Bank. Penlitian ini diharapkan mampu menganalisis tingkat kepercayaan masyarakat terhadap Bank Syariah Indonesia yaitu hasil dari Merger 3 Bank BUMN Syari'ah. penelitian ini menggunakan metode kuantitatif dan pengumpulan data dilakukan dengan metode perpustakaan dari jurnal, artikel, atau literatur yang terkait dengan data yang dibutuhkan, dan metode dokumentasi laporan pelaksanaan bank umum Syariah yang bersangkutan serta data dari situs OJK. Dalam penelitian ini dijelaskan bahwa merger bank Syariah memiliki pengaruh terhadap tingkat kepercayaan masyarakat. Masyarakat mengharapkan bahwa perbankan Syariah mampu bersaing dan mengingkatkan taraf hidup masyarakat.
\end{abstract}

Kata Kunci: Merger, Kepercayaan Masyarakat, Bank Syari'ah

\title{
PENDAHULUAN
}

Pertumbuhan dan perkembangan perbankan syari'ah di indonesia semakin meningkat. Hal ini dibuktikan dengan banyaknya usaha-usaha berbasis syari'ah. Perbankan Syari'ah terdiri dari Bank Umum Syari'ah (BUS), Unit Usaha Syari'ah (UUS), dan Bank Pembiayaan Rakyat Syari'ah (BPRS). Dimana Bank Syariah berdiri sendiri tanpa mengacu pada Bank Konvensional sebagai bank induknya. Semakin hari jumlah jaringan kantor Bank Syari'ah mengalami peningkatan. Hal ini diikuti dengan semakin baiknya layanan yang ada pada Bank Syariah dan menimbulkan banyaknya masyarakat yang mulai percaya dan berpindah kepada Bank Syari'ah. Perkembangan dan pertumbuhan perbankan dan lembaga keuangan serta bisnis syariah di Indonesia semakin membaik dari tahun ke tahun. Hal ini menunjukkan kenyataan diterimanya konsep syariah bagi masyarakat Indonesia. Islamic banks in Indonesia should be the locomotive of 
development and national economic growth because of Indonesia as a country with the largest population in the world and as the Muslim majority country(Nugroho et al., 2017). Bank Syariah secara yuridis normatif dan yuridisempiris diakui keberadaannya di Negara Republik Indonesia. Pengakuan secara yuridis normatitercatat dalam peraturan perundangundangan di Indonesia, diantaranya UU No. 10 Tahun 1998 Tentang Perubahan atas UU No. 7 Tahun 1992 Tentang Perbankan, UU No. 3 Tahun 2004 TentangPerubahan atas UU No. 23 Tahun 1999 Tentang Bank Indonesia, UU No. 3 Tahun 2006 TentangPerubahan Atas UU No. 7 Tahun 1989 Tentang Peradilan Agama.(Wiyono, 2021)

Menurut data OJK hingga tahun 2020, ada sekitar 189 bank syari'ah yang terdiri dari 14 Bank Umum Syari'ah, 20 Unit Usaha Syari'ah (UUS), dan 164 Bank Pembiayaan Rakyat Syari'ah (BPRS) di Indonesia. Perkembangan perbankan syariah di Indonesia menjadikan terwujudnya penggabungan (merger) 3 (tiga) perbankan syariah yang sudah ada yaitu Bank Syariah Mandiri (BSM), Bank Negara Indonesia Syariah (BNIS) dan Bank Rakyat Indonesia Syariah (BRIS). Adapun pengertian merger adalah suatu proses penggabungan dua perseroan dimana salah satunya tetap berdiri dan menggunakan nama perseroannya sementara perseroan yang lain lenyap dan semua kekayaannya dimasukkan ke dalam perseroan yang tetap berdiri tersebut. Ada juga yang menjelaskan bahwa pengertian merger adalah penggabungan dua perusahaan menjadi satu, dimana perusahaan yang melakukan merger mengambil alih semua aset dan kewajiban perusahaan yang menerima merger.(Yusuf \& Ichsan, 2021) Merger adalah salah satu bentuk ekspansi eksternal perusahaan dengan cara menggabungkan dua perusahaan atau lebih, dimana hanya satu nama perusahaan yang tetap berdiri sedangkan perusahaan lainnya bubar atas dasar hukum tanpa likuidasi terlebih dahulu.(Wiyono, 2021)

Penggabungan Bank Syari'ah menjadi Bank Syari'ah Indonesia tidak lepas dari kritikan dan berbagai kekhawatiran berbagai pihak utamanya nasib akses modal bagi usaha mikro dan kecil. Sebelumnya, Bank-bank syari'ah dapat menjadi andalan bagi pelaku usaha mikro dan kecil untuk 
mendapat akses modal guna mengembangkan usahanya. Namun, setelah penggabungan (merger) bank Syari'ah Indonesia dikhawatirkan tidak lagi mudah diakses oleh pelaku usaha berskala kecil karena lebih berorientasi terhadap usaha-usaha besar dan mapan. Kekhawatiran tersebut selaras dengan fakta bahwa penyelenggaraan ekonomi di dalam islam adalah untuk mencapai kesejahteraan Bersama baik di dunia dan untuk akhirat. Sehingga demikian, orientasi ekonomi tidak akan lagi berperan untuk membangun ekonomi umat sebagaimana fungsi dan tujuan dari eknomi islam itu sendiri.(Saputro, 2021)

Dalam kondisi perekonomian yang tidak menentu seperti sekarang, bank syariah harus mampu bekerja secara maksimal dalam membantu perekonomian nasional dengan konsep bagi hasil. Untuk memperkuat permodalan bank syariah di Indonesia dan agar memperluas kegiatan usahanya, maka muncul wacana untuk dilakukan ekspansi secara eksternal, dalam bentuk penggabungan usaha melalui merger beberapa bank syariah menjadi bank syariah BUMN. (Ahdizia, 2018) Merger bank syariah anak usaha BUMN diharapkan dapat membuka opsi-opsi pendanaan yang lebih luas di dalam negeri dan dapat membuat kinerjanya menjadi lebih baik dan efisien. Langkah ini juga diharapkan dapat membawa peningkatan market share perbankan syariah di Indonesia, serta dapat memberikan manfaat untuk semua pihak, baik perbankan syariah dan masyarakat untuk terus tumbuh dan berkembang. Melalui penggabungan semua bank syariah milik BUMN (merger), maka diharapkan adanya bank syariah BUMN yang tunggal akan memperkuat industri perbankan syariah dan semakin memperkuat pembiyaan ekonomi berbasis syariah di Indonesia.(Adinugraha \& Sartika, 2020)

Penelitian terdahulu yang dapat dijadikan dasar dari penelitian ini adalah penelitian Mohammad Yusuf dan Reza Nur Ichsani dengan judul Analysis of Banking Performance in The Aftermath of The Merger of Bank Syariah Indonesia in Covid-19 dan Penelitian Muhammad Umar Mail, dkk yang berjudul Pola Kinerja Perusahaan Sesudah Merger dan Akuisisi serta Analisis Terhadap Faktor-Faktor yang Mempengaruhinya. Dimana pada 
penelitian (Yusuf \& Ichsan, 2021) membahas tentang kinerja keuangan pada Bank Syariah Indonesia yaitu Bank hasil merger. Dalam penelitiannya menyatakan bahwa NPF dan BOPO memiliki pengaruh negatif dan signifikan sedangkan CAR dan dan FDR memiliki pengaruh positif namun tidak signifikan. Sedangkan pada penelitian (Nurdin et al., 2020) menyatakan bahwa Kinerja (ROI) yang dicapai perusahaan setelah melakukan merger danakuisisi meningkat secara signifikan sejalan dengan kenaikan TATO dan KURS. Selanjutnya, ROI setelah merger danakuisisi menurun ketika terjadi kenaikan tingkat bunga Bank Indonesia. Dari semua penelitian yang berkaitan dengan merger bank Syariah belum terdapat penelitian yang meneliti bagaimana tingkat kepercayaan masyarakat terhadap BSI yakni bank hasil merger.

Berdasarkan Fenomena di atas, sangat menraik apabila melakukan penelitian serta menganalisis bagaimana sikap para nasabah mendengar kabar adanya merger Bank BUMN Syari'ah. Karena kepercayaan sangatlah penting bagi keberlangsungan suatu bank maka hal ini perlu dilakukan guna mengetahui apa yang terjadi kepada kepercayaan nasabah Ketika terjadi merger Bank Syari'ah Indonesia dan menganalisis seberapa besar pengaruh merger Bank Syariah Indonesia terhadap Kepercayaan Masyarakat. Penelitian ini bertujuan untuk mengetahui kondisi tingkat kepercayaan masyarakat terhadap Bank Syari'ah Indonesia akibat merger yang dilakukan oleh 3 Bank BUMN Syari'ah. Berikut rincian rumusan masalahnya:

1. Apakah Merger Bank Syariah Indonesia memiliki pengaruh secara signifikan terhadap Tingkat Kepercayaan Masyarakat?

2. Bagaimana kondisi tingkat kepercayaan masyarakat akibat adanya merger Bank Syari'ah Indonesia?

\section{LANDASAN TEORI}

\section{Kepercayaan Masyarakat}

Kepercayaan adalah suatu penilaian hubungan dengan orang lain yang melakukan transaksi tertentu sesuai dengan harapan dalam sebuah lingkungan yang penuh ketidakpastian.(Ba \& Pavlou, 2002). (Butler Jr, 
1991) menjelaskan bahwa ada beberapa faktor kondisi yang dapat menyebabkan kepercayaan itu timbul diantaranya, keleluasaan, ketersediaan, kompetensi, konsistensi, pelaku adil, integritas, loyalitas, keterbukaan, kepercayaan secara keseluruhan, janji akan pemenuhan kebutuhan, dan penerimaan.(Delima \& Paramita, 2019) Menurut (Héliot et al., 2020) dalam (Nurrohmah \& Purbayati, 2020) Kepercayaan adalah wilayah psikologis yang merupakan perhatian untuk menerima apa adanya berdasarkan harapan terhadap perilaku yang baik dari orang lain

Mowen dan Minor menyatakan bahwa kepercayaan adalah semua pengetahuan yang dimiliki oleh konsumen dan semua kesimpulan yang dibuat kosumen tentang objek, atribut dan manfaatnya.(Mowen \& Minor, 2002) Menurut Mayer et al, kepercayaan konsumen dapat dipahami sebagai kesediaan satu pihak untuk menerima resiko dari tindakan pihak lain berdasarkan harapan bahwa pihak lain akan melakukan Tindakan penting untuk pihak yang mempercayainya, terlepas dari kemampuan untuk mengawasi dan mengendalikan tindakan pihak yang dipercayai.Dengan demikian kepercayaan adalah kemauan seseorang untuk bertumpu pada orang lain dimana kita memiliki keyakinan padanya.(Sari, 2020)

Untuk meyakinkan kepercayaan bank syariah terhadap masyarakat yaitu hendaknya bank tetap mempertahankan layanan yang sesuai dengan harapan nasabah sehingga konsumen tetap memilih bank syariah sebagai alternative utama dalam menabung. Kemudian pihak.(Delima \& Paramita, 2019). Kepercayaan menjadi salah satu faktor penting dalam membangun hubungan kemitraan antar bank syariah dengan nasabah. Tanpa adanya ke percayaan, suatu hubungan kerjasama tidak mungkin mampu ber tahan dalam jangka waktu lama. Kepercayaan timbul sebagai hasil dari kehandalan dan integritas mitra yang ditunjukkan melalui berbagai sikap, seperti konsistensi, kompeten, adil, ber tanggung jawab, suka menolong dan memiliki kepedulian. (Morgan \& Hunt, 1994) menambahkan pula, bahwa tingginya kepercayaan akan dapat berpengaruh terhadap menurunnya 
Trust (kepercayaan) juga memiliki pengertian suatu variabel kunci dalam memelihara suatu hubungan yang berkepanjangan seperti halnya pada suatu merk, atau trust terhadap suatu lembaga tertentu. Dengan hubungan yang berkelanjutan tersebut akan semakin meningkatkan terhadap harapan yang akan diterima dari perusahaan.(Janah, 2020) Semakin tinggi kepercayaan masyarakat terhadap image yang diberikan oleh industry maka masyarakat akan menjadi semakin yakin dan setia untuk menjadi nasabah terhadap industry tersebut khususnya perbankan syariah. Ketika nasabah puas akan pelayanan yang diberikan oleh industry perbankan syariah maka nasabah pun akan semakin setia terhadap perbankan Syariah.(Kinasih et al., 2019)

Dimensi yang dapat digunakan sebagai instrumen pengukuran percayaan antara lain:

\section{Kepuasan}

Kepuasan merupakan sikap terhadap hasil transaksi dan akan mempengaruhi perilaku selanjutnya dari nasabah, serta mempengaruhi sikap loyalitas nasabah. Kepuasan nasabah merupakan variabel mediator yang menghubungkan variabel kualitas layanan, keprcayaan, dan kesetiaan nasabah.

2. Skala interpersonal (interpersonal scale)

Dalam skala interpersonal diukur mengenai hubungan interpersonal, yaitu hubungan satu individu dengan individu lain yang ada dilingkunganya. Hubungan interpersonal juga dapat dipahami sebagai hubungan baik antara bank dan nasabah.

3. Terpercaya

Terpercaya berkenaan dengan kepercayaan nasabah pada kebaikan, kemampuan, kejujuran, integritas, keandalan, dan ketulusan dalam pelayanan yang diberikan. Dimensi yang dapat digunakan sebagai instrumen pengukuran

4. Hasil kepercayaan

Kepercayaan harus menimbulkan perilaku loyalitas nasabah sehngga terus menerus melakukan transaksi secara berulang- 
ulang. tiga faktor yang mempengaruhi kepercayaan yaitu: produk atau jasa yang disediakan itu sendiri, organisasi atau lembaga penyedia produk atau jasa, dan nasabah sebagai pelaku utama dalam transaksi tersebut.(Ningsih, 2019)

\section{Merger Bank Syariah}

Pengertian merger adalah penggabungan dua perusahaan atau lebih yang kemudian hanya ada satu perusahaan yang tetap hidup sebagai badan hukum, sementara yang lainnya menghentikan aktivitasnya atau bubar. Perusahaan yang dibubarkan mengalihkan aktiva dan kewajibannya ke perusahaan yang mengambil alih sehingga perusahaan yang mengambil alih mengalami peningkatan aktiva. Merger dan akuisisi telah diyakini percaya pemerintah, perusahaan, dan masyarakat luas sebagai suatu strategi untuk mempertahankan dan mengembangkan perusahaan. Sehingga gelombang merger dan akuisisi menjadi sangat populerdi negaranegara dunia, tidak terkecuali di Indonesia.(Nurdin et al., 2020) Performance evaluation according to Hameedis a method to measure the company's achievements based on the targets drawn up at the beginning. This becomes an important part of measuring control that can help the company improve its performance in the future. In Islam, the existence of performance evaluation is highly recommended.(Yusuf \& Ichsan, 2021) Pengumuman merger atau penggabungan suatu perusahaan merupakan salah satu bentuk pengumuman yang dapat memicu reaksi pasar. Ini didasarkan atas hasil beberapa penelitian sebelumnya mengenai reaksi pasar atas pengumuman merger suatu perusahaan, baik pada saat penandatanganan perjanjian bersyarat (Conditional Merger Agreement / CMA) maupun pada saat pengumuman diresmikannya merger.(Syamsuddin \& Pratama, 2021)

Pada tahun 2020, saat kondisi pandemi covid-19 menyebabkan kontraksi pada sebagian besar industri di dunia, ekonomi dan keuangan syariah tetap tumbuh positif. Momentum ini dimanfaatkan Pemerintah RI untuk meningkatkan peran ekonomi dan keuangan syariah dalam perekonomian nasional.(Mahargiyantie, 2021) Pada tahun 2020, terjadi 
merger antara tiga Bank Umum Syariah anak perusahaan Bank BUMN. Dimana pada akhir tahun 2020, telah ditetapkan nama dari hasil merger ketiga bank tersebut yaitu PT Bank Syariah Indonesia Tbk.(Biasmara \& Srijayanti, 2021) Penggabungan bank umum syariah pada masa pandemi merupakan langkah tepat untuk menjaga stabilitas perekonomian negara, sebagaimana tertuang dalam Perpu No.1 / 2020 dan POJK No.18 / POJK.03 / 2020. Dampak merger bank umum syariah, tentunya berdampak positif, bank syariah Indonesia dapat bersaing secara global dengan mengedepankan pelayanan yang lebih lengkap, coverage yang lebih luas, dan permodalan yang lebih baik. Bagi negara tentunya hal baik yang bisa dilakukan oleh Kementerian BUMN, dengan menginisiasi merger 3 anak perusahaan BUMN berbasis syariah (BNI Syariah, BSM, BRI Syariah) bergabung menjadi PT. Bank Syariah Indonesia, Tbk. (Atikah et al., 2021) Perbankan Syariah baru saja mencatatkan sejarah baru. Tiga Bank Syariah milik Pemerintah berhasil merger dengan nama Bank Syariah Indonesia (BSI). Tercatat kinerja semester I-2020 total aset BSI hasil merger mencapai Rp 214,6 triliun dengan modal inti lebih dari Rp 20,4 triliun. Dengan nilai aset dan modal inti tersebut, bank syariah hasil merger akan masuk jajaran 10 besar bank terbesar di Indonesia dari sisi aset segi kapitalisasi pasar. (Romadhon, 2021)

Ada beberapa jenis merger. Antara lain: merger horizontal, vertikal, dan konglomerat. Masing-masing memiliki ciri khasnya sendiri. Merger horizontal adalah proses penggabungan dua perusahaan atau lebih di mana jenis usaha perusahaannya masih sama. Seperti yang terjadi di industri perbankan. Kemudian merger vertikal. Merger vertikal adalah proses merger yang prakteknya terjadi peleburan antara beberapa perusahaan yang saling berhubungan. Umumnya, peleburan terjadi pada alur produksi. Merger seperti ini biasa terjadi di industri otomotif. Terakhir, merger konglomerat yang berarti penggabungan beberapa perusahaan untuk menghasilkan produk yang tidak ada kaitannya satu sama lain. Tujuan dari merger konglomerat adalah untuk meningkatkan pertumbuhan 
badan usaha. Praktik kerjanya umumnya dilaksanakan dengan cara saling bertukar saham antar perusahaan yang dileburkan.(Wiyono, 2021)

Tentunya merger dilakukan karena ada tujuan dan alasan tertentu yang ingin dicapai. adapun beberapa tujuan merger adalah sebagai berikut:

1. Pertumbuhan atau Diversifikasi

Suatu perusahaan dapat melakukan merger atau akuisisi bila ingin bertumbuh lebih cepat, baik ukuran, pasar saham, maupun diversifikasi usaha.

\section{Meningkatkan Dana}

Perusahaan yang ingin melakukan ekspansi internal pasti akan membutuhkan dana. Kebutuhan dana tersebut dapat diperoleh dengan melakukan ekspansi eksternal, yaitu menggabungkan diri dengan perusahaan yang mempunyai likuiditas tinggi.

\section{Menciptakan Sinergi}

Salah satu tujuan melakukan merger adalah untuk mencapai suatu sinergi, yaitu menghasilkan tingkat skala ekonomi. Sinergi akan terlihat jelas saat perusahaan melakukan peleburan dengan bisnis yang bentuk usahanya sama karena dapat melakukan efisiensi terhadap tenaga kerja dan fungsinya.

\section{Pertimbangan Pajak}

Pengeluaran untuk pajak bisa saja mengakibatkan kerugian bagi suatu perusahaan. Perusahaan yang mengalami kerugian pajak dapat meleburkan diri dengan perusahaan yang menghasilkan laba untuk memanfaatkan kerugian pajak. Dalam hal ini perusahaan yang melakukan akuisisi akan menaikkan kombinasi pendapatan sesudah pajak dengan mengurangi pendapatan sebelum pajak dari perusahaan yang telah diakuisisi.

5. Meningkatkan Keterampilan Perusahaan

Suatu perusahaan dapat mengalami kesulitan untuk berkembang karena kurangnya keterampilan dalam hal manajemen dan teknologi. Agar dapat mengatasi masalah tersebut, suatu 
perusahaan dapat bergabung dengan perusahaan lainnya yang memiliki manajemen dan teknologi yang mumpuni.

6. Melindungi Diri Dari Pengambilalihan

Setiap perusahaan berpotensi menjadi target pengambilalihan yang tidak bersahabat. Pelaku merger mengakuisisi perusahaan lain, dan membiayai pengambilalihannya dengan hutang, karena beban hutang ini maka kewajiban perusahaan menjadi terlalu besar untuk ditanggung oleh bidding firm yang berminat.

7. Meningkatkan Likuiditas Pemilik

Setiap perusahaan yang melakukan merger berpeluang untuk memiliki likuiditas yang lebih besar. Ketika perusahaan lebih besar, maka pasar saham akan lebih luas dan lebih mudah didapatkan sehingga lebih likuid ketimbang perusahaan kecil.

The merger of state-owned sharia banks aims increase the level of efficiency and productivity of Islamic banking in Indonesia. This is in line with the results of research from Ismail and Rahim (2009) which states that banks experience an increase in efficiency and higher productivity after the merger, where the sharia banking merger business will encourage technical changes or innovations to strengthen the Islamic economic order.(Tyas \& Rusydiana, 2020)

\section{Hipotesis Penelitian}

Istilah hipotesis berasal dari bahasa Yunani, yaitu dari kata hupo dan thesis. Hupo artinya sementara, atau kurang kebenarannya, atau lemah kebenarannya. Sedangkan thesis artinya pernyataan atau teori. Karena hipotesis adalah pernyataan sementara yang masih lemah kebenarannya, maka perlu diuji kebenarannya. Sehingga istilah hipotesis ialah pernyataan sementara yang perlu diuji kebenarannya.(Sholihin, 2020) Berdasarkan kerangka pemikiran teoritis dan hasil penemuan beberapa penelitian, maka hipotesis dapat dirumuskan sebagai berikut:

H0: Tidak ada pengaruh antara Merger Bank Syariah Indonesia terhadap Tingkat Kepercayaan Masyarakat 
H1: Merger Bank Syariah Indonesia berpengaruh positif dan signifikan terhadap Tingkat Kepercayaan Msyarakat.

\section{METODE PENELITIAN}

Jenis metode penelitian yang digunakan adalah kuantitatif. dan pengumpulan data dilakukan dengan metode perpustakaan dari jurnal, artikel, atau literatur yang terkait dengan data yang dibutuhkan, dan data dari situs OJK. Teknik pengumpulan data pada penelitian ini dengan menggunakan kuisioner. (Sholihin, 2020). Menurut Sugiyono, kuesioner atau angket merupakan teknik pengumpulan data yang dilakukan dengan cara memberi seperangkat pertanyaan atau pernyataan tertulis kepada responden untuk dijawabnya, dengan kategori 5 skor yaitu; Sangat Tidak Setuju, Tidak Setuju, Kurang Setuju, Setuju, dan Sangat Setuju.(Janah, 2020)

Teknik Analisis Data yang digunakan adalah sebagai berikut:

A. Uji Validitas dan Uji Reliabilitas

1. Uji Validitas

Pengujian Validitas data. uji validitas berguna untuk mengetahui apakah ada pertanyaanpertanyaan pada kuisioner yang harus dibuang/diganti karena dianggap tidak relevan.

2. Uji Reliabilitas

Reliabiltas (reliability) adalah suatu pengukur menunjukkan stabilitas dan konsistensi dari suatu instrumen yang, mengukur suatu konsep dan berguna untuk mengakses "kebaikan" dari suatu pengukur.

B. Uji Prasyarat

1. Uji Normalitas Data

Penggunaan model analisis pengaruh terikat dengan asumsi bahwa data harus distribusi normal agar diperoleh hasil yang tidak bias.

2. Uji Multikolinieritas 
Uji ini adalah menunjukan adanya hubungan linier yang sempurna atau mendekati sempurna diantara beberapa atau semua variabel.

3. Uji Heteroskedastisitas.

Uji heteroskedastisitas bertujuan untuk mengetahui apakah dalam model regresi terjadi ketidaksamaan varian dari suatu residual pengamatan ke pengamatan yang lain.

C. Analisis Regresi Linier Sederhana

Regresi linier sederhana adalah metode statsitik yang berfungsi untuk menguji sejauh mana hubungan sebab akibat antara variabel faktor penyebab $(\mathrm{X})$ terhadap variabel akibatnya $(\mathrm{Y})$.

D. Pengujian Hipotesis

Setelah dilakukan analisis regresi linier berganda kemudian dilakukan pengujian hipotesis yang digunakan untuk mengetahuapakah terdapat pengaruh dan seberapbesar pengaruh variabel independent terhadap variabel dependen baik secarparsial maupun simultan.

1. Uji t (Uji Parsial).

Uji t digunakan untuk mengetahui pengaruvariabel independen terhadap variable independen secara parsial yang diuji dengacara signifikansi.

2. Uji $F$ (Uji Simultan)

Uji F digunakan untuk mengetahui pengaruh variabel independen terhadap variable dependen secara simultan yang diuji dengan cara signifikansi.(Sholihin, 2020)

\section{HASIL DAN PEMBAHASAN}

Hasil dari pelaksanaan penelitian ini bersumber dari penyebaran kuisioner dengan responden adalah masyarakat dari berbagai kalangan. Dari seluruh kuesioner yang didapat terdapat beberapa deskripsi yang dapat digunakan untuk menggambarkan sampel yang digunakan. Adapun Variabel Independen dan dependen dari penelitian ini meliputi:

$\mathrm{X}$ : sebagai Merger Bank Syariah 
Y: sebagai Kepercayaan Masyarakat

Agar memudahkan penelitian berikut adalah hasil dari pengklasifikasian data responden berdasarkan Usia, jenis Kelamin, dan Pekerjaan.

Tabel 1. Usia Responden

\begin{tabular}{|c|c|c|}
\hline No & Usia & Jumlah \\
\hline 1 & $<20$ Tahun & 5 \\
\hline 2 & $\begin{array}{c}20-35 \\
\text { Tahun }\end{array}$ & 23 \\
\hline 3 & $>35$ tahun & 14 \\
\hline
\end{tabular}

Tabel 2. Jenis Kelamin Responden

\begin{tabular}{|c|c|c|}
\hline No. & $\begin{array}{c}\text { Jenis } \\
\text { kelamin }\end{array}$ & Jumlah \\
\hline 1 & Laki-laki & 28 \\
\hline 2 & Perempuan & 14 \\
\hline
\end{tabular}

Tabel 3. Pekerjaan Responden

\begin{tabular}{|c|c|c|}
\hline No. & Pekerjaan & Jumlah \\
\hline 1 & Mahasiswa/pelajar & 22 \\
\hline 2 & Guru/pendidik & 14 \\
\hline 3 & Karyawan swasta & 3 \\
\hline 4 & Pengawas & 2 \\
\hline 5 & Petani & 1 \\
\hline
\end{tabular}

\section{Uji Validitas}

Uji Validitas Variabel X (Merger Bank Syariah)

\section{Correlations}

\begin{tabular}{|c|c|c|c|c|c|c|c|}
\hline & & $\mathrm{X} 1$ & $x 2$ & X3 & $\times 4$ & $\times 5$ & $X$ \\
\hline $\mathrm{X} 1$ & $\begin{array}{l}\text { Pearson } \\
\text { Correlation } \\
\text { Sig. (2-tailed) } \\
\text { N }\end{array}$ & 42 & $\begin{array}{l}, 562^{\star *} \\
, 000 \\
42\end{array}$ & $\begin{array}{l}, 634^{\star *} \\
, 000 \\
42\end{array}$ & $\begin{array}{l}, 437^{\star *} \\
, 004 \\
42\end{array}$ & $\begin{array}{l}, 173 \\
, 274 \\
42\end{array}$ & \begin{tabular}{|l}
, $787^{* \star}$ \\
, 000 \\
42
\end{tabular} \\
\hline$X 2$ & $\begin{array}{l}\text { Pearson } \\
\text { Correlation } \\
\text { Sig. (2-tailed) } \\
\mathrm{N}\end{array}$ & $\begin{array}{l}, 562^{* \star} \\
, 000 \\
42\end{array}$ & 42 & $\begin{array}{l}, 783^{\star \star} \\
, 000 \\
42\end{array}$ & $\begin{array}{l}, 480^{* *} \\
, 001 \\
42\end{array}$ & $\begin{array}{l}, 071 \\
, 657 \\
42\end{array}$ & $\begin{array}{l}, 824^{* \star} \\
, 000 \\
42\end{array}$ \\
\hline
\end{tabular}




\begin{tabular}{|c|c|c|c|c|c|c|c|}
\hline X3 & $\begin{array}{l}\text { Pearson } \\
\text { Correlation } \\
\text { Sig. (2-tailed) } \\
\text { N }\end{array}$ & $\begin{array}{l}, 634^{* *} \\
, 000 \\
42\end{array}$ & $\begin{array}{l}, 783^{* *} \\
, 000 \\
42\end{array}$ & 42 & $\begin{array}{l}, 587^{* *} \\
, 000 \\
42\end{array}$ & $\begin{array}{l}, 214 \\
, 173 \\
42\end{array}$ & $\begin{array}{l}, 898^{* *} \\
, 000 \\
42\end{array}$ \\
\hline X4 & $\begin{array}{l}\text { Pearson } \\
\text { Correlation } \\
\text { Sig. (2-tailed) } \\
\mathrm{N}\end{array}$ & $\begin{array}{l}.437^{* *} \\
.004 \\
42 \\
\end{array}$ & $\begin{array}{l}, 480^{* *} \\
, 001 \\
42 \\
\end{array}$ & $\begin{array}{l}, 587^{* *} \\
, 000 \\
42 \\
\end{array}$ & 42 & $\begin{array}{l}, 475^{* *} \\
, 001 \\
42\end{array}$ & $\begin{array}{l}, 770^{* *} \\
000 \\
42\end{array}$ \\
\hline X5 & $\begin{array}{l}\text { Pearson } \\
\text { Correlation } \\
\text { Sig. (2-tailed) } \\
\mathrm{N}\end{array}$ & $\begin{array}{l}, 173 \\
, 274 \\
42 \\
\end{array}$ & $\begin{array}{l}.071 \\
.657 \\
42 \\
\end{array}$ & $\begin{array}{l}, 214 \\
, 173 \\
42 \\
\end{array}$ & $\begin{array}{l}, 475^{* *} \\
, 001 \\
42 \\
\end{array}$ & 42 & $\begin{array}{l}, 410^{* *} \\
, 007 \\
42 \\
\end{array}$ \\
\hline$X$ & $\begin{array}{l}\text { Pearson } \\
\text { Correlation } \\
\text { Sig. (2-tailed) } \\
\mathrm{N}\end{array}$ & $\begin{array}{l}, 787^{* *} \\
.000 \\
42 \\
\end{array}$ & $\begin{array}{l}, 824^{* *} \\
.000 \\
42 \\
\end{array}$ & $\begin{array}{l}, 898^{* *} \\
, 000 \\
42 \\
\end{array}$ & $\begin{array}{l}, 770^{* *} \\
, 000 \\
42 \\
\end{array}$ & $\begin{array}{l}.410^{* *} \\
.007 \\
42 \\
\end{array}$ & 42 \\
\hline
\end{tabular}

${ }^{* \star}$. Correlation is significant at the 0.01 level (2-tailed).

Validitas Y (Tingkat Kepercayaan Masyarakat)

Correlations

\begin{tabular}{|c|c|c|c|c|c|c|c|}
\hline & & $\mathrm{Y} 1$ & $\mathrm{Y} 2$ & Y3 & Y4 & $\mathrm{Y} 5$ & $Y$ \\
\hline Y1 & $\begin{array}{l}\text { Pearson } \\
\text { Correlation } \\
\text { Sig. (2-tailed) } \\
\mathrm{N}\end{array}$ & 41 & \begin{tabular}{|l}
$.534^{* *}$ \\
.000 \\
40 \\
\end{tabular} & $\begin{array}{l}, 399^{* *} \\
, 010 \\
41 \\
\end{array}$ & $\begin{array}{l}, 481^{* *} \\
, 002 \\
40 \\
\end{array}$ & \begin{tabular}{|l}
, $731^{* *}$ \\
, 000 \\
41 \\
\end{tabular} & $\begin{array}{l}, 792^{* *} \\
, 000 \\
41 \\
\end{array}$ \\
\hline Y2 & $\begin{array}{l}\text { Pearson } \\
\text { Correlation } \\
\text { Sig. (2-tailed) } \\
\mathrm{N}\end{array}$ & $\begin{array}{l}.534^{* *} \\
.000 \\
40 \\
\end{array}$ & 41 & $\begin{array}{l}.597^{* *} \\
, 000 \\
41 \\
\end{array}$ & $\begin{array}{l}, 494^{* *} \\
, 001 \\
40 \\
\end{array}$ & $\begin{array}{l}.371^{*} \\
.017 \\
41 \\
\end{array}$ & $\begin{array}{l}, 754^{* *} \\
, 000 \\
41 \\
\end{array}$ \\
\hline Y3 & $\begin{array}{l}\text { Pearson } \\
\text { Correlation } \\
\text { Sig. (2-tailed) } \\
\mathrm{N}\end{array}$ & $\begin{array}{l}, 399^{* *} \\
.010 \\
41 \\
\end{array}$ & $\begin{array}{l}.597^{* *} \\
, 000 \\
41 \\
\end{array}$ & 42 & $\begin{array}{l}, 611^{* *} \\
, 000 \\
41 \\
\end{array}$ & $\begin{array}{l}.615^{* *} \\
, 000 \\
42 \\
\end{array}$ & $\begin{array}{l}, 782^{* *} \\
, 000 \\
42 \\
\end{array}$ \\
\hline Y4 & $\begin{array}{l}\text { Pearson } \\
\text { Correlation } \\
\text { Sig. (2-tailed) } \\
\mathrm{N}\end{array}$ & $\begin{array}{l}.481^{* *} \\
, 002 \\
40 \\
\end{array}$ & $\begin{array}{l}.494^{* *} \\
, 001 \\
40 \\
\end{array}$ & $\begin{array}{l}, 611^{* *} \\
, 000 \\
41 \\
\end{array}$ & 41 & $\begin{array}{l}.408^{* *} \\
, 008 \\
41 \\
\end{array}$ & $\begin{array}{l}, 721^{* *} \\
, 000 \\
41 \\
\end{array}$ \\
\hline
\end{tabular}




\begin{tabular}{|ll|l|l|l|l|l|l|} 
Y5 & $\begin{array}{l}\text { Pearson } \\
\text { Correlation } \\
\end{array}$ &, $731^{* *}$ &, $371^{*}$ &, $615^{* *}$ &, $408^{* *}$ & 1 &, $779^{* *}$ \\
& Sig. (2-tailed) &, 000 &, 017 &, 000 &, 008 & &, 000 \\
\hline Y & $\begin{array}{l}\text { Pearson } \\
\text { Correlation }\end{array}$ &, $792^{* *}$ &, $754^{* *}$ &, $782^{* *}$ &, $721^{* *}$ &, $779^{* *}$ & 1 \\
& Sig. (2-tailed) &, 000 &, 000 &, 000 &, 000 &, 000 & \\
& N & 41 & 41 & 42 & 41 & 42 & 42 \\
\hline
\end{tabular}

**. Correlation is significant at the 0.01 level (2-tailed).

*. Correlation is significant at the 0.05 level (2-tailed).

Hasil pengamatan pada rTabel didapatkan nilai dari sampel $(\mathrm{N})=42$ sebesar 0,3044 . Merujuk pada hasil dari uji validitas dapat disimpulkan bahwa semua instrument variable $X$ (merger bank Syariah) yang terdiri dari X1, X2, X3, X4 dan X5 menghasilkan nilai (rHitung) > (rTabel). Selain itu variable $Y$ (tingkat kepercayaan masyarakat) yang terdiri dari $Y 1, Y 2, Y 3$, Y4, dan Y5 menghasilkan nilai (rHitung) > (rTabel). Sehingga dapat disimpulkan bahwa semua instrument pada penelitian ini adalah valid.

\section{Uji Reliabilitas}

Uji Reliabilitas Variabel X (Merger Bank Syariah)

Reliability Statistics
\begin{tabular}{|l|l|}
\hline $\begin{array}{l}\text { Cronbach's } \\
\text { Alpha }\end{array}$ & $\begin{array}{l}\mathrm{N} \\
\text { Items }\end{array}$ \\
\hline, 813 & 5 \\
\hline
\end{tabular}

Uji Reliabilitas Variabel Y (Tingkat Kepercayaan Masyarakat)

Reliability Statistics
\begin{tabular}{|l|l|}
\hline $\begin{array}{l}\text { Cronbach's } \\
\text { Alpha }\end{array}$ & $\begin{array}{l}\mathrm{N} \\
\text { Items }\end{array}$ \\
\hline, 842 & 5 \\
\hline
\end{tabular}

Dari hasil uji reliabilitas didapatkan semua nilai dari hasil variable $X$ dan $Y$ semuanya menghasilkan nilai alpha cronbach $>0,6$. Sehingga dapat disimpulkan semua instrument dalam penelitian ini adalah Reliabel. 


\section{Uji Normalitas}

One-Sample Kolmogorov-Smirnov Test

\begin{tabular}{|c|c|c|}
\hline & & $\begin{array}{l}\text { Unstandardi } \\
\text { zed } \\
\text { Residual }\end{array}$ \\
\hline $\mathrm{N}$ & & 42 \\
\hline Normal Parameters ${ }^{a, b}$ & Mean & ,0000000 \\
\hline & Std. & 2,87651565 \\
\hline Extreme & Aheolute & nan \\
\hline Differences & Positive &, 090 \\
\hline & Negative &,- 081 \\
\hline Test Statistic & &, 090 \\
\hline Asymp. Sig. (2-tailed) & &, $200^{c, d}$ \\
\hline
\end{tabular}
a. Test distribution is Normal.
b. Calculated from data.
c. Lilliefors Significance Correction.
d. This is a lower bound of the true significance.

Dari hasil uji normalitas menggunakan metode kolomogrov smirnov didapatkan hasil signifikansi dari uji normalitas sebesar 0,200 dimana hasil tersebut lebih besar dari taraf signifikansi 0,05, sehingga dapat disimpulkan uji normalitas pada penelitian ini adalah terdistribusi normal.

\section{Uji Multikolinearitas}

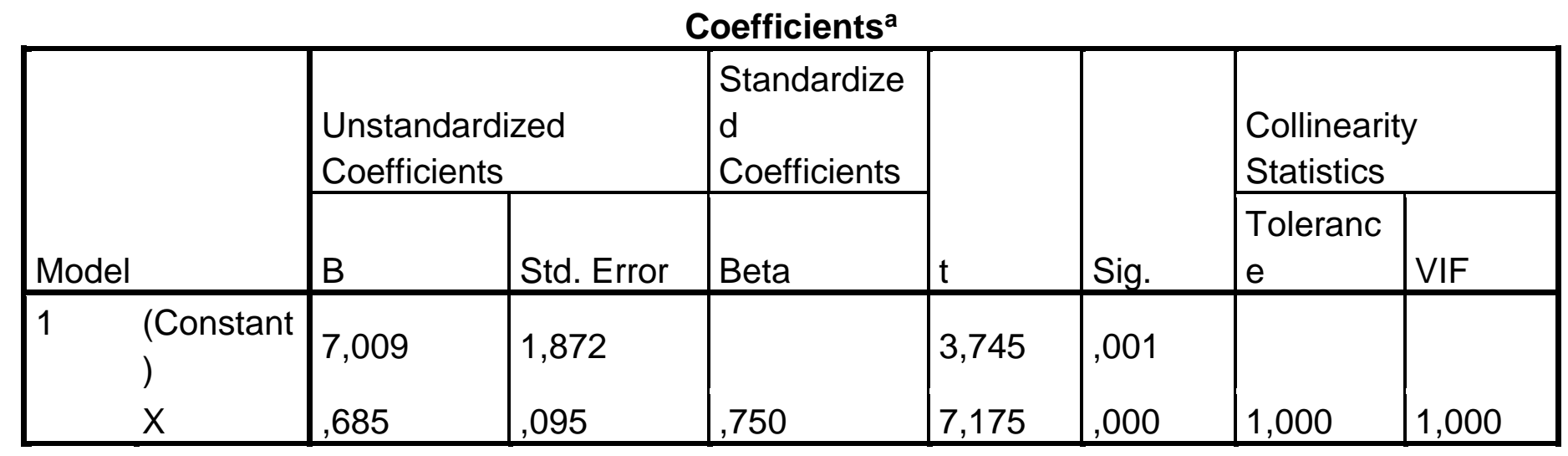

a. Dependent Variable: $Y$ 
Dari hasil perhitungan yang ada pada table hasil uji multikolinearitas, variable bebas menunjukkan bahwa nilai VIF = 1 dimana nilai tersebut lebih kecil dari 10, sehingga dapat disimpulkan bebas dari multikolinearitas.

\section{Uji Heterokedastisitas}

\begin{tabular}{|c|c|c|c|c|c|}
\hline \multicolumn{6}{|c|}{ Coefficients $^{a}$} \\
\hline \multirow[b]{2}{*}{ Model } & \multicolumn{2}{|c|}{$\begin{array}{l}\text { Unstandardized } \\
\text { Coefficients }\end{array}$} & \multirow{2}{*}{$\begin{array}{l}\text { Standardize } \\
\text { d } \\
\text { Coefficients } \\
\text { Beta }\end{array}$} & \multirow[b]{2}{*}{$\mathrm{t}$} & \multirow[b]{2}{*}{ Sig. } \\
\hline & B & Std. Error & & & \\
\hline $\begin{array}{ll}1 & \text { (Constant } \\
& \\
x\end{array}$ & $\begin{array}{l}4,135 \\
-, 099\end{array}$ & $\begin{array}{l}1,103 \\
, 056\end{array}$ &,- 268 & $\begin{array}{l}3,748 \\
-1,762\end{array}$ & $\begin{array}{l}, 001 \\
, 086\end{array}$ \\
\hline
\end{tabular}

a. Dependent Variable: RES_2

Dari hasil uji multikolinearitas menggunakan uji glejser hasil signifikan dari variabel bebas atau variabel $X$ menunjukkan sebesar 0,086 diatas dari nilai standar signifikansi 0,05 . Sehingga dapat disimpulkan bahwa tidak terjadi masalah heterokedastisitas.

Uji Autokorelasi

\begin{tabular}{|l|l|l|l|l|l|}
\hline $\begin{array}{l}\text { Mode } \\
\text { I }\end{array}$ & $\mathrm{R}$ & $\begin{array}{l}\mathrm{R} \\
\text { Square }\end{array}$ & $\begin{array}{l}\text { Adjusted } \\
\text { Square }\end{array}$ & $\begin{array}{l}\text { Std. Error of } \\
\text { the Estimate }\end{array}$ & $\begin{array}{l}\text { Durbin- } \\
\text { Watson }\end{array}$ \\
\hline 1 &, $750^{\mathrm{a}}$ &, 563 &, 552 & 2,912 & 2,071 \\
\hline
\end{tabular}

a. Predictors: (Constant), $\mathrm{X}$

b. Dependent Variable: $Y$

Berdasarkan hasil table uji autokolerasi diketahui untuk nilai DW = 2,071, dibandingkan dengan nilai table signifikansi $5 \%(0,05)$ dengan jumlah sampel 42 variabel independent $1(K=1)=1,42$ sehingga didapatkan hasil dU dari table $r=1,544$. Nilai DW lebih besar dari batas dU dan DW kurang dari (4-dU) $=4-1,544=2,456$. Sehingga dapat disimpulkan bahwa tidak terdapat autokorelasi.

\section{Analisis Regresi Linier Sederhana}

$Y=a+b X$

Keterangan: 
$\mathrm{Y}=$ Variabel Terikat (Dependen) Tingkat Kepercayaan Nasabah

$\mathrm{a}=$ Nilai Koefisien

$\mathrm{b}=$ Koefisien Regresi

$\mathrm{X}=$ Variabel Bebas (Independen) Merger Bank Syariah

\section{Pengujian Hipotesis}

Uji F

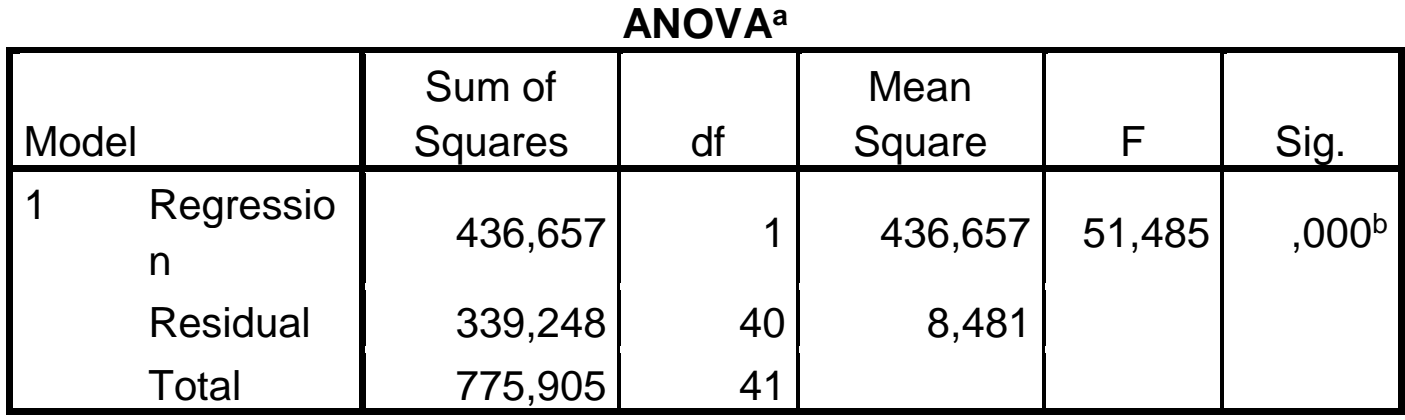

a. Dependent Variable: $Y$

b. Predictors: (Constant), $X$

Untuk persamaan regresi ini didapat hasil bahwa Sig. sebesar 0,0001

kurang dari 0,05 dengan demikian disimpulkan bahwa terdapat pengaruh signifikan antara variabel Merger Bank syariah $(\mathrm{X})$ terhadap variabel Tingkat Kepercayaan Masyarakat (Y) secara simultan.

Uji t

\section{Coefficients $^{\mathrm{a}}$}

\begin{tabular}{|c|c|c|c|c|c|}
\hline \multirow[b]{2}{*}{ Model } & \multicolumn{2}{|c|}{$\begin{array}{c}\text { Unstandardized } \\
\text { Coefficients }\end{array}$} & \multirow{2}{*}{$\begin{array}{c}\text { Standardize } \\
\text { d } \\
\text { Coefficients } \\
\text { Beta } \\
\end{array}$} & \multirow[b]{2}{*}{$\mathrm{T}$} & \multirow[b]{2}{*}{ Sig. } \\
\hline & $B$ & Std. Error & & & \\
\hline $\begin{array}{ll}1 \quad \text { Constant } \\
\end{array}$ & 7,009 & 1,872 & & 3,745 & 001 \\
\hline$x$ & ,685 & ,095 & ,750 & 7,175 &, 000 \\
\hline
\end{tabular}

a. Dependent Variable: $Y$ 


\section{Uji Koefisien Determinasi}

\begin{tabular}{|c|c|c|c|c|}
\hline \multicolumn{5}{|c|}{ Model Summary } \\
\hline $\begin{array}{l}\text { Mode } \\
1\end{array}$ & $\mathrm{R}$ & $\begin{array}{c}\mathrm{R} \\
\text { Square }\end{array}$ & $\begin{array}{c}\text { Adjusted R } \\
\text { Square }\end{array}$ & $\begin{array}{c}\text { Std. Error of } \\
\text { the } \\
\text { Estimate }\end{array}$ \\
\hline 1 &, $750^{a}$ & ,563 & ,552 & 2,912 \\
\hline
\end{tabular}

a. Predictors: (Constant), $\mathrm{X}$

Tujuan dari uji t adalah untuk pengujian hipotesis secara parsial atau individu untuk masing -masing variabel melalui pengujian model dari data diatas diketahui bahwa setiap variabel bebas berpengaruh signifikan secara parsial terhadap variabel terikat

Dari hasil beberapa pengujian yang dilakukan terdapat beberapa pembahasan yang didapat. Secara parsial Merger Bank Syariah $(X)$ memiliki berpengaruh siginifikan terhadap Tingkat Kepercayaan Masyarakat $(Y)$ secara parsial dari hasil perhitungan melalui bantuan SPSS yang menunjukkan hasil 0,001, hal ini dikarenakan Merger Bank Syariah diharapkan mampu membantu masyarakat dalam hal keuangan dan meningkatkan pertumbuhan ekonomi Indonesia khususnya Perbankan Syariah di skala internasional. Karena seperti yang telah diketahui bahwa semakin hari Perbankan Syariah menunjukkan sisi positif dan kehadirannya mampu menjadi salah satu hal yang harus dibanggakan oleh Indonesia. Walau untuk saat ini Perbankan Syariah di Malaysia masih unggul dalam hal ekonomi Syariah tapi hal tersebut tidak menutup kemungkinan untuk Indonesia mencapai bahkan menggesernya, terlebih Indonesia sendiri adalah negara dengan mayoitas muslim terbesar di dunia. Dengan adanya hal tersebut harusnya Indonesia bisa lebih berhasil dalam Ekonomi berbasis Syariah khususya di Perbankan Syariah. Dukungan masyarakat berupa kepercayaan mereka sangat penting untuk perbankan Syariah melaju dan mampu bersaing nantinya. 


\section{KESIMPULAN}

Berdasarkan hasil dan pembahasan dalam penelitian ini, maka dapat disimpulkan bahwa Merger Bank Syariah berpengaruh positif dan signifikan terhadap tingkat kepercayaan masyarakat. Dengan adanya merger bank Syariah ini maka semakin meningkatkan kepercayaan masyarakat untuk menabung pada Bank Syariah, hal ini dapat dilihat dari dorongan masyarakat kepada Bank Syariah untuk memberikan kualitas yang semakin baik dan meminta Bank Syariah Indonesia mampu membantu meningkatkan taraf hidup masyarakat. Dengan adanya merger ini juga masyarakat berharap bahwa nantinya Bank Syariah Indonesia mampu bersaing dan membawa dampak positif bagi Perbankan Syariah di Indonesia maupun di mancanegara.

Kondisi tingkat kepercayaan masyarakat saat ini sedang meningkat dan menunjukkan perubahan yang positif terhadap Perbankan Syariah sehingga menjadikan Perbankan Syariah lebih yakin untuk memperluas Perbankan Syariah ke seluruh penjuru dunia dan dapat menjadi role model bagi negara negara lain untuk menerapkan system perbankan Syariah. Dengan bergabungnya 3 Bank BUMN Syariah ini diharapkan nantinya mereka tidak perlu bersaing satu sama lain akan tetapi Bersatu untuk bersaing dengan Bank yang lain untuk menunjukkan keberadaan Bank Syariah sangat mempengaruhi perkembangan perekonomian Indonesia.

\section{DAFTAR PUSTAKA}

Adinugraha, H. H., \& Sartika, M. (2020). PERBANKAN SYARIAH: Fenomena Terkini dan Praktiknya di Indonesia. Penerbit NEM.

Ahdizia, K. (2018). ANALISIS PENILAIAN BISNIS BANK SYARIAH DALAM RANGKA RENCANA MERGER MENJADI BANK SYARIAH BUMN.

Atikah, I., Maimunah, M., \& Zainuddin, F. (2021). Penguatan Merger Bank Syariah BUMN dan Dampaknya Dalam Stabilitas Perekonomian Negara. SALAM: Jurnal Sosial Dan Budaya Syar-I, 8(2).

Ba, S., \& Pavlou, P. A. (2002). Evidence of the effect of trust building technology in electronic markets: Price premiums and buyer behavior. MIS Quarterly, 243-268.

Biasmara, H. A., \& Srijayanti, P. M. R. (2021). Mengukur Kinerja Pra Merger 
Tiga Bank Umum Syariah dan Pengaruhnya Terhadap Return on Asset. Moneter-Jurnal Akuntansi Dan Keuangan, 8(1), 70-78.

Butler Jr, J. K. (1991). Toward understanding and measuring conditions of trust: Evolution of a conditions of trust inventory. Journal of Management, 17(3), 643-663.

Delima, M., \& Paramita, M. (2019). Analisis Kemudahan Akses Terhadap Kepercayaan Masyarakat Pada Bank Syariah (Studi Bank BRI Syariah KCP Palabuhanratu). Nisbah: Jurnal Perbankan Syariah, 5(1), 75-82.

Héliot, Y., Gleibs, I. H., Coyle, A., Rousseau, D. M., \& Rojon, C. (2020). Religious identity in the workplace: A systematic review, research agenda, and practical implications. Human Resource Management, 59(2), 153-173.

Janah, N. (2020). Pengaruh Tingkat Pengetahuan dan Kepercayaan Nasabah Terhadap Minat Menabung di Bank Syariah. IAIN Metro.

Kinasih, H. W., Isthika, W., \& Oktafiyani, M. (2019). Pengukuran kualitas perbankan syariah sebagai upaya dalam peningkatan kesetiaan nasabah. Jurnal Akuntansi Indonesia, 8(1), 75-88.

Mahargiyantie, S. (2021). PERAN STRATEGIS BANK SYARIAH INDONESIA DALAM EKONOMI SYARIAH DI INDONESIA. ALMISBAH, 2(2).

Morgan, R. M., \& Hunt, S. D. (1994). The commitment-trust theory of relationship marketing. Journal of Marketing, 58(3), 20-38.

Mowen, J. C., \& Minor, M. (2002). Perilaku konsumen. Jakarta: Erlangga, 90.

Ningsih, A. S. W. (2019). KOMITMEN, KEPERCAYAAN DAN KEPUASAN NASABAH TERHADAP LOYALITAS NASABAH DI BANK PEMBIAYAAN RAKYAT SYARIAH SARANA PRIMA MANDIRI PAMEKASAN.

Nugroho, L., Utami, W., Doktorlina, C. M., Soekapdjo, S., \& Husnadi, T. C. (2017). Islamic banking capital challenges to increase business expansion (Indonesia cases).

Nurdin, A. A., Mai, M. U., \& Setiawan, S. (2020). Pola Kinerja Perusahaan Sesudah Merger dan Akuisisi serta Analisis Terhadap Faktor-Faktor yang Mempengaruhinya. Jurnal Riset Akuntansi Dan Keuangan, 8(2), 431-446.

Nurrohmah, R. F., \& Purbayati, R. (2020). Pengaruh Tingkat Literasi Keuangan Syariah dan Kepercayaan Masyarakat terhadap Minat Menabung di Bank Syariah. Jurnal Maps (Manajemen Perbankan Syariah), 3(2), 140-153.

Romadhon, B. (2021). Korelasi Merger Tiga Bank Syariah dan Kesadaran Masyarakat Terhadap Produk Perbankan Syariah. Jurnal At-Tamwil: 
Kajian Ekonomi Syariah, 3(1), 86-98.

Saputro, A. W. (2021). Potensi Praktik Monopoli dalam Merger Bank Syariah Indonesia: Tinjauan Hukum Ekonomi Islam dan Hukum Larangan Monopoli. Jurnal Hukum Lex Generalis, 2(2), 174-194.

Sari, R. N. (2020). Kepercayaan masyarakat pada Lembaga Keuangan Mikro Syariah di Kecamatan Rumbia. IAIN Metro.

Sholihin, M. R. (2020). Analisis Faktor-Faktor Yang Mempengaruhi Tingkat Kepercayaan Masyarakat terhadap Lembaga Keuangan Syariah. Jurnal IImiah Ecobuss, 8(1), 21-27.

Syamsuddin, S., \& Pratama, V. Y. (2021). The Announcement of Sharia Bank's Conditional Merger Agreement. How Investor Reacted? Journal of Business Management Review, 2(2), 136-146.

Tyas, A. A., \& Rusydiana, A. S. (2020). The Productivity of Pre-Merger State-Owned Islamic Banks in Indonesia. Ekonomi Islam Indonesia, 2(2).

Wiyono, W. M. (2021). Dampak Merger 3 (Tiga) Bank Syariah Bumn Terhadap Perkembangan Ekonomi Syariah. Cakrawala Hukum: Majalah IImiah Fakultas Hukum Universitas Wijayakusuma, 23(1), 6573.

Yusuf, M., \& Ichsan, R. N. (2021). Analysis of Banking Performance in The Aftermath of The Merger of Bank Syariah Indonesia in Covid 19. International Journal of Science, Technology \& Management, 2(2), 472-478. 